\title{
Miroslav Novák a kol.: Strany, volby a demokracie: Od Duvergera, $k$ Sartorimu a dále
}

Praha: SLON, 2016. 1. vyd., 516 s., ISBN 978-80-7419-233-3

\section{DANIEL KEREKES ${ }^{1}$}

V roku 2016 vyšla vo vydavatel'stve SLON kolektívna monografia pod vedením Miroslava Nováka Strany, volby a demokracie s príznačným podnázvom Od Duvergera k Sartorimu a dále. Kniha je nepochybne cenným prírastkom do českoa slovenskojazyčnej politologickej knižnej zbierky.

Publikácia si kladie pomerne ambiciózny ciel' prediskutovat', eventuálne uzavriet' a ozrejmit', vybrané sporné alebo problémové oblasti súčasnej politickej teórie a politologického výskumu. Editor ich vyčlenil do týchto troch oblastí: stranícke systémy, vzt’ahy volebných a straníckych systémov a empirické teórie demokracie. Podl'a tohto kl'úča je kniha rozdelená do troch častí. Celkovo má kniha 16 kapitol a svojimi textami sa na nej podiel’alo spolu 14 autorov - spája tak poznatky mladšej a staršej generácie politológov.

$* * *$

Prvú čast' knihy otvára kapitola o rolách a vzt'ahu straníckych a parlamentných funkcionárov, ktoré autorka Pavla Zetková zasadzuje do kontextu typológie politických strán. Nesporným prínosom tejto kapitoly je diskusia nad nejasnými konceptami, ako napríklad „kartelová strana“, a tiež reflexia týchto konceptov v súčasnom svete straníckej politiky. Kapitola tiež analyzuje a hodnotí český stranícky systém. Možno by kapitolu urobilo ešte prínosnejšou, ak by sa v nej autorka viac a presnejšie venovala definičným aspektom jednotlivých konceptov z typológie strán.

Nasledujúca kapitola venuje pozornost' dvom konceptom - Duvergerovej dominantnej strane a Sartoriho predominantnej strane, pričom diskutuje a upresňuje definičné podmienky oboch konceptov. Autor Miloš Brunclík správne zdôrazňuje potrebu odlišovat' a nezamieňat' typológiu straníckych systémov

\footnotetext{
${ }^{1}$ Interní doktorand, Katedra politologie, Fakulta sociálních studií, Masarykova univerzita, Joštova 10, 60200 Brno / Department of Political Science, Faculty of Social Studies, Masaryk University, Brno, Czech Republic. E-mail: kerekes@mail.muni.cz.
} 
a typológiu strán $\mathrm{v}$ týchto systémoch. Oba koncepty autor rozsiahle ilustruje na škandinávskych straníckych systémoch, čo je čitatel'sky zaujímavá čast' textu, avšak, obávam sa, významne neprispieva knaplneniu ciel’a recenzovanej monografie.

Ďalej sa v tretej kapitole Michal Kubát krátko, ale vecne venuje konceptu antisystémovej strany. V súčasnej dobe rastúcej popularity protestných a antisystémových strán, z čoho vyplýva aj nárast záujmu o výskum tejto problematiky, je táto kapitola hodnotnou súčast’ou publikácie - predovšetkým preto, že upresňuje definíciu pojmu a ponúka návod pre jeho metodologické uchopenie.

$\mathrm{Na}$ kapitolu nadväzuje reflexia Sartoriho koncepcie polarizovaného pluralizmu, pričom v úvode state sa správne poukazuje na nutnost' rozlišovat' medzi straníckym systémom a stranícko-politickým zriadením. Maximilián Strmiska d’alej v kapitole koncepciu polarizovaného pluralizmu účinne diskutuje v kontexte talianskej straníckej politiky. Kapitola prispieva k pochopeniu pojmu, tiež prehlbuje diskusiu o ňom, avšak málo ponúka čo do metodologického uchopenia problematiky.

Prvú čast' knihy uzatvára kapitola Lady Šušlíkovej, ktorá vyčerpávajúco opisuje taliansky stranícky systém a jeho vývoj. Taliansky stranícky systém je pre čitatel'ovu mysel' svojim spôsobom uvol'nením po náročnej teoretickej diskusii. Nezodpovedaná však ostáva otázka potreby prítomnosti danej state vo vzt’ahu $\mathrm{k}$ ciel'om tejto monografie. Kapitola síce výberom geograficko-politického prípadu nadväzuje na predchádzajúcu kapitolu, no čitatel’ovi nie je zrejmé, prečo práve taliansky stranícky systém má uzatvárat' čast' knihy, ktorá je venovaná teoretickej a konceptuálnej diskusii o stranách a straníckych systémoch.

$* * *$

Druhá čast' recenzovanej monografie sa nesie v znamení vzt’ahu volebných a straníckych systémov, pričom klúčová je otázka, či podoba volebného systému skutočne determinuje podobu systému straníckeho.

Túto čast' knihy uvádza kapitola Miroslava Nováka, ktorá je vynikajúcim príspevkom do diskusie nad danou problematikou. Autor v kapitole analyzuje pôvodné prachom prekryté Duvergerove diela a pokúša sa dovysvetlit' problematiku tzv. Duvergerových zákonov. Okrem iného tým aj obhajuje Duvergera pred kritikou, ktorej niekedy neprávom kvôli týmto zákonom čelí. Miroslav Novák v kapitole podrobne jednotlivé zákony rozoberá a upresňuje aj ich metodologické uchopenie. Kapitole by bolo možné vyčítat' vyžarujúci, trochu nekritický, obdiv k Duvrgerovi.

Nasleduje kapitola Ivana Jarabinského a Romana Chytileka o strategickom hlasovaní, ktorá okrem definovania a diskusie nad definíciou strategického hlasovania ponúka aj podrobnú a komentovanú typológiu. Akademicky prínosnou je predovšetkým podkapitola, ktorá sa venuje málo populárnemu okruhu, 
a to strategickému hlasovaniu v pomerných volebných systémoch. Navyše, kapitola otvára nemenej dôležitú otázku operacionalizácie strategického hlasovania, pričom sa snaží ponúknut' aj jej konkrétne riešenia.

Kapitola Jakuba Charváta vyčerpávajúco popisuje politiku volebných reforiem, typológiu procesov a ich bariéry. Čitatel'ovi ponúka zaujímavú debatu o vývoji vnímania volebných systémov ako (ne)závislej premennej. Charvát svojou kapitolou nepochybne prispieva k búraniu mýtu o jednosmernosti kauzality vo vzt’ahu volebných a straníckych systémov. Možno na škodu danej kapitoly je, že sa nepokúša o načrtnutie akéhosi praktického rámca pre výskum volebných reforiem.

$\mathrm{Na}$ kapitolu o volebných reformách trefne nadväzuje rozsiahla debata o kauzalite vzt'ahu straníckych a volebných systémov. Karel Kouba v nej otvára možnost' endogenity, teda situácie, kedy volebné systémy, ako nezávislá premenná straníckym systémom, môže byt' v skutočnosti závislá na svojej závislej premennej. Táto stat' je hodnotná aj kvôli metodologickému návodu, ktorý čitatel'ovi ponúka.

Druhú čast' knihy, podobne ako tú prvú, uzatvára prípadová štúdia Nového Zélandu. Autor Matěj Trávniček si za ciel kladie aplikovat' Duvergerove zákony v praxi. Kapitola vyčerpávajúco opisuje novozélandský stranícky systém pred reformou, priebeh reformy a následky reformy. Kapitola však v skutočnosti málo reflektuje Duvergerove zákony a málo nadväzuje na predchádzajúcu debatu v knihe.

Tretia čast' je venovaná v politológii večne živej téme, či je „lepšia“ proporčnost’ alebo akcieschopnost’. Už samotný názov tejto časti - „Demokracie rozhodná, nebo bezmocná?“ - dáva trochu tušit', za ktorý koniec v nej bude autor a editor publikácie t’ahat'. Čast' otvára krátka, ale výstižná kapitola Miroslava Nováka, v ktorej približuje klasifikáciu straníckych systémov podl’a Duvergera. Znovu pritom analyzuje Duvergerove pôvodné diela. Kapitola d’alej plynule prechádza do debaty o typoch demokracie. Zmyselná je hlavne čast', kde autor vysvetl'uje rozdiely medzi „efficiency“ a „effectivness“/ „performance“, a ako tieto jazykovo podobné koncepty zavádzajú pri porovnávaní väčšinových a konsenzuálnych modeloch demokracie.

Nasleduje čitatel'sky prít'ažlivá diskusia medzi R. B. Andewegom a A. Lijphartom, ktorú následne komentuje Miroslav Novák. Je nutné poznamenat', že ide o eseje, ktoré už boli v minulosti publikované a táto kniha ponúka ich český preklad. Andeweg diskutuje rozpor medzi rannými a neskoršími prácami a (normatívnymi) postojmi Lijpharta. Lijphart túto kritiku čiastočne prijíma a upresňuje. Pre súčasnost' je v tomto smere obzvlášt' zaujímavá diskusia nad pôvodom pravicového populizmu v konsenzuálnych demokraciách. Kým Andeweg naznačuje, že pravicový populizmus pramení v nedostatočnej sút’aží 
politických elít v konsenzuálnych deomkraciách, Lijphart tvrdí, že pravicový populizmus netreba preceňovat' a že je iba akousi externalitou proporčných volebných systémov.

Tretiu čast' knihy uzatvára voči Lijphartovi pomerne kritická kapitola, v ktorej Miroslav Novák vecne kritizuje Lijphartovo preferovanie konsenzuálneho modelu, pričom sa poukazuje predovšetkým na nesprávnost' niektorých jeho argumentov v prospech konsenzuálneho modelu. Miroslav Novák čast' knihy vyhradenú modelom demokracie uzatvára s tým, že v otázke proporčnosti alebo akcieschopnosti nie je možné maximalizovat' oboje a je nutné si vyberat'.

Hoci úvod publikácie slubuje čitatel'ovi rozdelenie knihy do troch častí, za tou tret'ou ešte formálne nasleduje čast' štvrtá. Tá predstavuje akýsi rozšírený záver publikácie. Zvláštnost'ou však je, že záver sa nelimituje len na sumarizovanie publikácie, ale otvára a diskutuje aj v knihe nepreberané témy.

Celkovo možno publikáciu hodnotit' vel'mi dobre. Jej silnou stránkou je fakt, že sa venuje v politickej vede sporným oblastiam a snaží sa vyvracat' niektoré mýty; napr. o kauzalite medzi volebnými a straníckymi systémami. Kladne možno hodnotit' aj snahu upresňovat' koncepty a prehlbovat' znalost' o nich. Výbornú prácu odviedol Miroslav Novák vysvetl'ovaním a interpretovaním pôvodných Duvergerových a Sartoriho prác. Akademická obec určite ocení aj tie časti publikácie, ktoré k rozoberaným témam prinášajú aj metodologické návody.

Čitatel'sky pútavo pôsobia vložky v podobe prekladov esejí Andewega a Lijpharta a editorova reflexia $\mathrm{k}$ nim. Otázne však je, do akej miery eseje zapadajú do celkovej štruktúry publikácie. Tá môže pôsobit' trochu nejednoznačne. Pre pomerne všeobecne stanovený ciel' publikácie, t’ažko hodnotit' prínos jednotlivých kapitol (príspevkov) k jeho naplneniu. Každopádne, niektoré kapitoly v publikácii pôsobia ako diskusné eseje a iné majú zase skôr učebnicový (prehl'adový) charakter. Čitatel'ovi nemusí byt' vždy jasné, či ide o zborník esejí alebo tematický zameranú kolektívnu publikáciu. Ak by malo íst' o to druhé, tak knihe, ale aj čitatelovi, by pomohla jednotnejšia štruktúra, a zároveň jasnejšia previazanost' kapitol.

V publikácii je zjavný odmietavý postoj editora k Lijphartovmu konsenzuálnemu modelu. Miroslav Novák venuje kritike Lijpharta pomerne vela priestoru, pričom Duvergera v publikácii často a nekriticky vyzdvihuje. Tento postoj zvláštne vrcholí na strane 383, kde je Lijphartova pozícia prirovnaná až k detinskému názoru.

Kolektívnu monografiu Strany, volby a demokracie môžem odporučit' každému, kto sa zaujíma o vol'by, volebné a stranícke systémy či fungovanie demokracií. Publikáciu určite ocenia aj čitatelia klasických Duvergerových, Sartoriho a Lijphartových diel, nakol'ko je ich interpretáciám a reflexiám v publikácii venované množstvo priestoru. 